\title{
AKR1C3 Gene
}

National Cancer Institute

\section{Source}

National Cancer Institute. AKR1C3 Gene. NCI Thesaurus. Code C129052.

This gene is involved in the conversion of aldehydes and ketones to alcohols. 